Journal of Humanities and Social Sciences Studies (JHSSS)

ISSN: 2663-7197

DOI: $10.32996 /$ jhsss

Journal Homepage: www.al-kindipublisher.com/index.php/jhsss

\title{
The Effect of Adversity Quotient on Psychology Capital and Performance: Evidence from Indonesian Teachers
}

\author{
Moh. Alifuddin ${ }^{1}$ (D) and W. Widodo ${ }^{2}$ (D) $ه$ \\ ${ }^{1}$ STMIK Handayani Makassar, Sulawesi Selatan, Indonesia \\ ${ }^{2}$ Universitas Indraprasta PGRI, Jakarta, Indonesia
}

$\triangle$ Corresponding Author: W. Widodo, E-mail: widmag@gmail.com

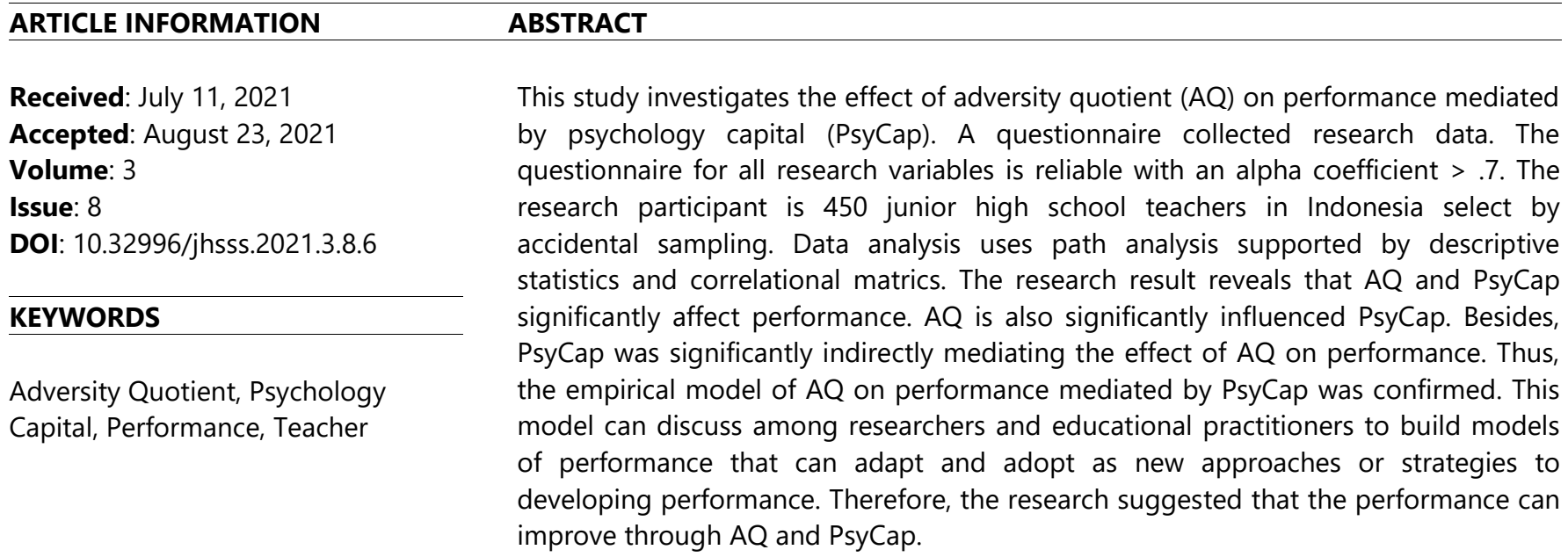

\section{Introduction}

In organizational dynamics, individual performance has always been an exciting issue due to several surprising facts. First, employee performance is suspected not only of having a significant effect on organizational performance (Fahmi, Musnadi, \& Nadirsyah, 2019) but has also been convincingly proven to increase organizational effectiveness (Tahsildari \& Shahnaei, 2015). Second, employees' performance is also influenced organization competitiveness (Falola, Osibanjo, \& Ojo, 2014). This empirical fact encourages academics, researchers, and organizational and management practitioners to place individual (employee) performance at the center of continuous study, research, and discussion. The estuary, of course, is not only trying to explore the factors that trigger an increase or decrease in performance but, more than that, finding appropriate ways to maintain and improve individual performance in the context of organizational life. That urgency is the concern and the aim of this study at the same time.

Performance is a set of employee work-related behaviors designed to accomplish organizational goals (Ivancevich, Konopaske, \& Matteson 2018; Colquitt, Lepine, \& Wesson, 2019). In practice, performance can view from a perspective on contextual performance, which includes those behaviors that contribute to the organizations' effectiveness by providing a suitable environment in which task performance can occur, such as persisting with enthusiasm and exerting extra effort as necessary to complete one's task activities successfully; volunteering to carry out task activities that are not formally part of the job; helping and cooperating with others; following organizational rules and procedures; and endorsing, supporting, and defending organizational objectives (Aguinis, 2018). The behavior that reflects the individuals' performance does not occur by itself but is at least influenced by two factors, namely $A Q$ and PsyCap.

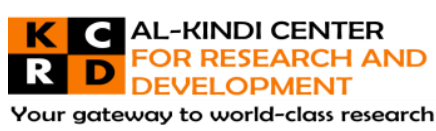

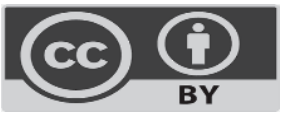

Published by Al-Kindi Center for Research and Development. Copyright (c) the author(s). This open access article is distributed under a Creative Commons Attribution (CC-BY) 4.0 license 


\section{$A Q$ and Performance}

Like performance, in the last two decades, AQ has attracted many parties' attention because of its phenomenal existence. AQ has been claimed to helps individuals strengthen their abilities and perseverance in facing the challenges of everyday life (Ablaña, Isidro, \& Cabrera, 2016). In the educational context, AQ proves can enhancing graduates' quality (Puspitacandri et al., 2020). Besides, AQ is also related to organizational citizenship behavior (Siphai, 2015) and affective commitment (Aryani, Widodo, \& Chandrawaty, 2021). Moreover, in the organizational context, AQ can be reducing turnover intention (Youngjin \& Sujeong, 2020). AQ is a persons' ability to survive in the face of difficulties and efforts to resolve difficulties (Hastuti, Sari, \& Riyadi, 2018). AQ also refers to a persons' capacity to deal with and respond to lifes' difficulties, such as stress and the difficulties he faces (Tigchelaar $\&$ Bekhet, 2015). Stoltz (2007) mentions four AQs' dimensions: control, origin ownership, reach, and endurance (CO2RE). Control refers to the ability of individuals to positively influence a situation and control the response to the situation. Origin ownership reflects the individuals' ability to place feelings on them and dare to bear the consequences of the situation, improving the problems. Reach is related to an individuals' ability to reach out and limit problems to reach other areas of an individuals' life. Endurance is individuals' ability to perceive difficulties and strength in dealing with these difficulties by creating ideas for problem-solving so that the hardness of heart and courage in solving problems can be realized. This dimension, if the high condition can enhancing performance, is reflected in persisting with enthusiasm and exerting extra effort as necessary to complete ones' task activities successfully; volunteering to carry out task activities that are not formally part of the job; helping and cooperating with others; following organizational rules and procedures; and endorsing, supporting, and defending organizational objectives (Aguinis, 2018). The recent studies also claimed that AQ affects performance (e.g., Runtu, Aldrin, \& Merdiaty, 2019; Sujana, Suardikha, \& Pratiwi, 2019; Uzoho \& Akudo, 2019; Wolor et al., 2020; Tansiongco \& Ibarra, 2020; Muztaba, Bahri, Farizal, 2020; Effendi et al., 2020; Hidayati \& Taufik, 2020). Based on the argument and studies above, can formulate the hypotheses:

\section{$H_{1}$ : AQ has a direct effect on performance.}

\section{PsyCap and Performance}

Various studies in multiple fields and contexts indicated that Psycap has contributed to individuals' behavior and career. Carmona-Halty, Schaufeli, and Salanova (2019) prove that Psycap affects academic performance in the educational field. Other studies revealed that PasyCap is related to career outcomes (Baluku et al., 2021) and organizational citizenship behavior (e.g., Chamisa, Mjoli, \& Mhlanga, 2020; Waters et al., 2020). The recent studies also claimed that PsyCap influences innovative behavior (Slatten et al., 2020; Wang, Chen, \& Zhu, 2021). Previous studies have shown that PsyCap is essential for the lives of individuals, so it is essential to pay attention, especially concerning organizations.

PsyCap is a basic competency that plays a vital role for employees to handle awareness, strive and achieve efficiency (Cavus \& Gokcen, 2015). PsyCap also refers to an individuals' positive and developmental state characterized by self-efficacy, optimism, hope, and resiliency (Luthan \& Youssef-Morgan, 2017). Self-efficacy refers to an individuals' belief in their capabilities to complete tasks. Optimism is based on the clear appraisal and judgment of current situations and understanding what can be done in such situations. Hope is an individuals' belief in their determination to achieve their goals and find possible pathways to overcome difficulties. Finally, resilience refers to the ability to recover from adversity or setbacks, proactively rise to challenges, and adapt to an ever-changing business environment (Tang et al., 2019). The four indicators: self-efficacy, optimism, hope, and resilience, if in good conditions, it has the potential to enhance performance among teachers, which is manifested in persisting with enthusiasm and exerting extra effort as necessary to complete ones' task activities successfully; volunteering to carry out task activities that are not formally part of the job; helping and cooperating with others; following organizational rules and procedures; and endorsing, supporting, and defending organizational objectives (Aguinis, 2018). Several studies by scholars are concluded that PsyCap influences performance (e.g., Luthans, Luthans, \& Chaffin, 2018; Alessandri et al., 2018; Carmona-Halty, Schaufeli, \& Salanova, 2019; Rodríguez-Cifuentes et al., 2020; Imran \& Shahnawaz, 2020; Alias et al., 2020; Ali et al., 2021). Based on the argument and research results above, can formulate the hypotheses:

\section{$\mathrm{H}_{2}$ : PsyCap has a direct effect on performance.}

\section{$A Q$ and PsyCap}

AQ is also affecting PsyCap besides performance. Although studies on the relationship between AQ and PsyCap are still minimal, research carried out by Septria and Rusli (2019) indicates that AQ is related to PsyCap. Once again, this empirical fact shows the vitality of AQs' existence in individual life, including the organizational life dynamics. In reality, the teachers in high control, origin ownership, reach, and endurance (Stoltz, 2007) can improving teachers' PsyCap, such as self-efficacy, optimism, hope, and resilience (Luthans \& Youssef-Morgan, 2017). For example, teachers with adequate ownership, reach, and endurance tend to have high optimism, hope, and resilience. Based on the studies and arguments above, can formulate the hypotheses: 
$H_{3}$ : AQ has a direct effect on PsyCap.

\section{AQ and Performance Mediated by PsyCap}

From the various studies above, PsyCap mediates AQs' effect on performance. As an illustration, the teachers in high control, origin ownership, reach, and endurance (Stoltz, 2007) can drive improving teachers' PsyCap, such as self-efficacy, optimism, hope, and resilience (Luthans \& Youssef-Morgan, 2017) and then implicate to performance manifested in persisting with enthusiasm and exerting extra effort as necessary to complete ones' task activities successfully; volunteering to carry out task activities that are not formally part of the job; helping and cooperating with others; following organizational rules and procedures; and endorsing, supporting, and defending organizational objectives (Aguinis, 2018). The research carried out by Septria and Rusli (2019) proved that AQ has a significant correlation with PsyCap, while several scholars claimed that PsyCap affects performance (e.g., Saithong-in \& Ussahawanitchakit, 2016; Wahyuningsih \& Wulansari, 2016; Saif ur Rehman, Qingren, \& Latif, 2017; Ortega-Maldonado \& Salanova, 2017; Santos, Reis Neto, \& Verwaal, 2018; Carmona-Halty et al., 2018; Şen \& Basim, 2018; Tüzün, Çetin, \& Basim, 2018). Based on the argument and studies above, can formulate the hypotheses:

$\mathrm{H}_{4}$ : AQ had an indirect effect on performance mediated by PsyCap.

\section{Methods}

This research uses a quantitative approach to the survey method through a Likert scale model questionnaire with five option answers: strongly disagree, disagree, neutral, agree, and strongly agree to verify the hypotheses (Hair et al., 2018). The questionnaire makes researchers themselves based on the theoretical dimensions or indicators from the experts. The AQs' dimensions: control, origin ownership, reach, endurance (Stoltz, 2007). Psycap indicators are self-efficacy, optimism, hope, and resilience (Luthans \& Youssef-Morgan, 2017). The performance consists of five indicators: persisting with enthusiasm and exerting extra effort as necessary to complete one's task activities successfully; volunteering to carry out task activities that are not formally part of the job; helping and cooperating with others; following organizational rules and procedures; and endorsing, supporting, and defending organizational objectives (Aguinis, 2018). AQ consists of 8 items with an alpha coefficient $=.820$, PsyCap consists of 12 items with an alpha coefficient $=.930$, and performance consists of 10 items with alpha coefficients $=.879$. All variables have an alpha coefficient > .7, so it is reliable as a research instrument (Griethuijsen et al., 2014; Hair et al., 2018).

The research participant is 450 teachers of the junior high school in Indonesia spread across seven provinces (Jakarta, Banten, West Java, Central Java, Riau Island, NTT, and East Kalimantan) determined by accidental sampling based on participant willingness to fill in the questionnaire at the time the research was conducted (Widodo, 2019).

Table 1: Profile of The Research Participant

\begin{tabular}{lcc}
\hline \multicolumn{1}{c}{ Profile } & Amount & Percentage \\
\hline Gender & & \\
1. Male & 141 & 31.33 \\
2. Female & 309 & 68.67 \\
Age & & \\
1. $\leq 25$ years & 34 & 7.56 \\
2. $26-35$ years & 159 & 35.33 \\
3. $36-45$ years & 111 & 24.67 \\
4. 46-55 years & 111 & 24.67 \\
5. $\geq 56$ years & 35 & 7.78 \\
Education & & \\
1. Diploma (D3) & 19 & 4.22 \\
2. Bachelor (S1) & 405 & 90 \\
3. Postgraduate (S2) & 26 & 5.78 \\
4. Doctoral (S3) & 0 & 0 \\
Status & & \\
1. Married & 360 & 80 \\
2. Unmarried & 90 & 20 \\
Length of Teaching & & \\
1. $\leq 5$ years & 127 & 28.22 \\
2. 6 - 10 years & 83 & 18.44 \\
3. 11 - 15 years & 100 & 22.22 \\
& & \\
& &
\end{tabular}



4. $\geq 16$ years
140
31.11

As present in Table 1, the majority of gender is female (68.67\%), ages 26 - 35 years (35.33\%), bachelor education (90\%), marital status (80\%), and length of teaching $\geq 16$ years (31.11\%). Data analysis by path analysis and test the significance of the path coefficient uses a t-test supported by correlational and descriptive statistics. Descriptive analyzes were performed by SPSS version 22, while the path analysis was by LisRel 8.80 .

\section{Result and Discussion}

The descriptive statistical analysis result for the three research variables are present as follows in Table 2 . The mean values of the three variables from the lowest to the highest in succession are AQ (33.42), performance (39.91), and PsyCap (48.41). The correlation analysis results in all variables have significant relationships with the other variables at level $p<.01$. This condition indicates that all the variables have a mutual relationship with each other. The correlation coefficient from the lowest to the highest in succession are AQ and performance (.567), PsyCap and performance (.591), and AQ and PsyCap (.644).

Table 2: Descriptive Statistics and Correlation Matrix

\begin{tabular}{lccccc}
\hline \multicolumn{1}{r}{ Variables } & Mean & Std. Deviation & $\mathbf{1}$ & $\mathbf{2}$ & $\mathbf{3}$ \\
\hline 1. AQ & 33.42 & 3.543 & 1.00 & & \\
2. PsyCap & 48.41 & 5.176 & $.644^{\star *}$ & 1.00 & \\
3. Performance & 39.91 & 5.260 & $.567^{* *}$ & $.591^{* *}$ & 1.00 \\
\hline$* * p<.01$ & & & &
\end{tabular}

The results of hypothesis testing with path analysis of AQs' effect on performance mediated by PsyCap are summarized in Table 3 and visualized in Figure 1 and Figure 2. All of the hypotheses were supported ( $\mathrm{t}$ value $>\mathrm{t}$ table at $\alpha=.01$ ). Therefore the result of this study revealed that $A Q$ has a significant direct effect on performance $(.32, p<.01)$, PsyCap has a significant direct effect on performance $(.39, \mathrm{p}<.01)$, AQ has a significant direct effect on PsyCap $(.65, \mathrm{p}<.01)$, and AQ had a significant indirect effect on performance mediating by PsyCap $(.25, \mathrm{p}<.01)$.

Table 3: Summary of Path Coefficients and T Values

\begin{tabular}{lccc}
\hline \multicolumn{1}{c}{ Hypothesis } & Path Coefficients & T Value & Hypothesis Testing \\
\hline $\mathrm{H}_{1}$ : AQ $(\mathrm{X})$ on performance $\left(\mathrm{Y}_{2}\right)$ & $.32^{* *}$ & 6.67 & Supported \\
$\mathrm{H}_{2}$ : PsyCap $\left(\mathrm{Y}_{1}\right)$ on performance $\left(\mathrm{Y}_{2}\right)$ & $.39^{\star *}$ & 8.15 & Supported \\
$\mathrm{H}_{3}$ : AQ $(\mathrm{X})$ on PsyCap $\left(\mathrm{Y}_{1}\right)$ & $.65^{\star *}$ & 17.86 & Supported \\
$\mathrm{H}_{4}$ : AQ $(\mathrm{X})$ on performance $\left(\mathrm{Y}_{2}\right)$ mediated by PsyCap $\left(\mathrm{Y}_{1}\right)$ & $.25^{\star *}$ & 7.42 & Supported \\
\hline$* *$
\end{tabular}

** $p<.01$

In Figure 1 and Figure 2, the test results of the model with the goodness of fit statistics show the significant with Chi-Square $=$ $0.000, \mathrm{df}=0, \mathrm{p}$-value $=1.00000>.05$ and RMSEA $=.000<.08$. That means the model tested is fit. This result indicates that the theoretical test model is supported by empirical data from the junior high schools' teachers in Indonesia spread across seven provinces (Jakarta, Banten, West Java, Central Java, Riau Island, NTT, and East Kalimantan).

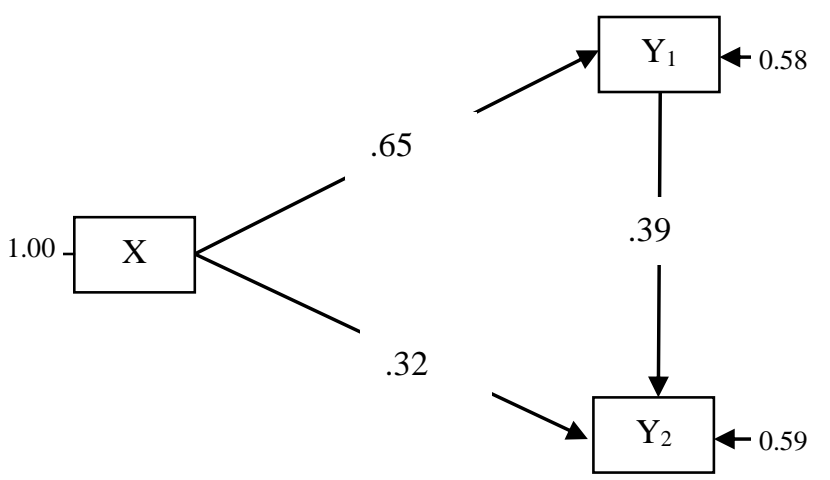

Chi-Square $=0.00, \mathrm{df}=0, \mathrm{p}$-value $=1.00000>.05$, RMSEA $=.000$

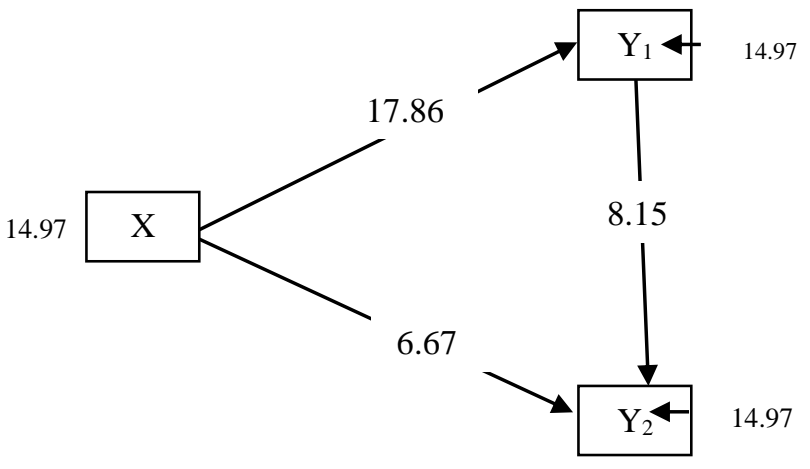

Chi-Square $=0.00, \mathrm{df}=0, \mathrm{p}$-value $=1.00000>.05$, RMSEA $=.000$ 
This research proved that $A Q$ significantly affected performance, directly or indirectly mediating by PsyCap. It shows two critical pieces of evidence. First, the vitality of AQ and PsyCap for teachers' performance. That means the existence of AQ and PsyCap are important determinants for improving teachers' performance. This is similar and consistent with studies conducted by researchers that performance influenced by AQ (e.g., Runtu, Aldrin, \& Merdiaty, 2019; Sujana, Suardikha, \& Pratiwi, 2019; Uzoho \& Akudo, 2019; Wolor et al., 2020), and PsyCap (e.g., Rodríguez-Cifuentes et al., 2020; Imran \& Shahnawaz, 2020; Alias et al., 2020; Ali, et al., 2021). This empirical fact confirms that AQ and PsyCap are vital for teachers' performance, so that it needs to maintain, manage, and develop optimally. Consequently, school principals need to more attention to increasing teachers' $A Q$ and PsyCap. In this context, school principals need to encourage schools to become learning organizations that allow teachers' $A Q$ and Psycap to grow naturally and even more fertile to improve teacher performance. These efforts should focus on seeding $A Q$ indicators (control, origin ownership, reach, endurance) and PsyCap (self-efficacy, optimism, hope, resilience).

Second, OCB plays a significant role as a mediator of the effect of AQ on teachers' performance. This finding not only confirms the results of previous research conducted by Septria and Rusli (2019) that AQ has a significant relationship with PsyCap as well as studies by scholars that PsyCap affects performance (e.g., Luthans, Luthans, \& Chaffin, 2018; Alessandri et al., 2018; CarmonaHalty, Schaufeli, \& Salanova, 2019) but more than that it also shows a new model of the influence of AQ on performance with PsyCap mediation as a novelty. This new model can be discussed among scholars, researchers, and practitioners to build a performance model that can adapt to improving performance, including teachers.

\section{Conclusion}

This study investigates the effect of $A Q$ on performance mediated by PsyCap. The result found that $A Q$ and PsyCap significantly affect performance. AQ is also significantly influenced teachers' PsyCap. Besides, PsyCap is indirectly mediating the effect of AQ on teachers' performance. Therefore, the new empirical model of AQ on performance mediating by PsyCap was confirmed. This new model can discuss among researchers and practitioners to build models of performance that can adapt to improving performance. Hence, the research suggested that the teachers' performance can improve through AQ and PsyCap. For researchers, this new model can be applied to educational organizations or other organizations to develop and expand research more comprehensively, for example adding new variables, other dimensions, or analytical approaches, such as structural equation modeling (SEM) that processing use SmartPLS. Furthermore, researchers can also expand the research area, for example, by adding samples (participants) from other provinces in Indonesia. For practitioners, the model significantly can improve teacher performance by simultaneously considering AQ and PsyCap conditions. However, this requires goodwill from the principal through strategic policies specifically scheduled to improve teacher performance as an essential capital to help students who face difficulties in achieving their best academic achievements, especially during the Covid-19 pandemic. The success of schools in improving teacher performance will provide a multiplier effect for improving school organization and education quality.

Funding: This research received no external funding.

Acknowledgments: We are very grateful to the teachers in Indonesia who volunteered to spend their time and complete dedication to responding to every statement item in the questionnaire completely and perfectly so that it could be used as research material in this article. May this willingness and dedication be a contribution to the development of science that can seeding to civilization.

Conflicts of Interest : The authors declare no conflict of interest.

\section{References}

[1] Ablaña, M. V. V., Isidro, D. J., \& Cabrera, G. A. (2016). Correlation between adversity quotient and job performance of LGU employees of Tayabas City: input to effective public personnel management. Journal of Research of the College of Arts and Sciences, Southern Luzon State University, Lucban, Quezon, PH, 8(2), 109-122.

[2] Aguinis, H. (2018). Performance management (4th ed.). Illinois: Chicago Business Press.

[3] Alessandri, G., Consiglio, C., Luthans, F., \& Borgogni, L. (2018). Testing a dynamic model of the impact of psychological capital on work engagement and job performance. Career Development International, 23(1), 33-47. https://doi.org/10.1108/CDI-11-20160210.

[4] Ali, I., Khan, M. M., Shakeel, S., \& Mujtaba, B. G. (2021). Impact of psychological capital on performance of public hospital nurses: The mediated role of job embeddedness. Public Organization Review, 1-20. https://doi.org/10.1007/s11115-021-00521-9.

[5] Alias, N. E., Abu, N., Koe, W-L., Marmaya, N. H., \& Romaiha, R. O. N. R. (2020). Does psychological capital matter for the public sector employees? A survey of the impact of psychological capital on individual job performance in Malaysia. International Journal Academic Research in Business and Social Sciences, 10(8), 772-787. https://doi.org/10.6007/IJARBSS/v10-i8/7625.

[6] Aryani, R., Widodo, W., \& Chandrawaty, C. (2021). How adversity quotient and organizational justice reduce turnover intention empirical evidence from Indonesia. Journal of Asian Finance, Economics and Business, 8(6), 1171-1181. https://doi:10.13106/jafeb.2021.vol8.no6.1171

[7] Baluku, M. M., Mugabi, E. N., Nansamba, J., Matagi, L., Onderi, P., \& Otto, K. (2021). Psychological capital and career outcomes among final year university students: the mediating role of career engagement and perceived employability. International Journal of Applied Positive Psychology, 6, 55-80. https://doi.org/10.1007/s41042-020-00040-w 
[8] Carmona-Halty, M., Schaufeli, W. B., \& Salanova, M. (2019). Good relationships, good performance: The mediating role of psychological capital-a three-wave study among students. Frontier in Psychology, 10(306), 1-5. https://doi.org/10.3389/fpsyg.2019.00306.

[9] Çavus, M. F., \& G€okçen, A. (2015). Psychological capital: definition, components, and effects. British Journal of Education, Society \& Behavioural Science, 5(3), 244-255. https://doi: 10.9734/BJESBS/2015/12574

[10] Chamisa, S. F., Mjoli, T. Q., \& Mhlanga, T.S. (2020). Psychological capital and organizational citizenship behavior in selected public hospitals in the Eastern Cape Province of South Africa. SA Journal of Human Resource Management/SATydskrif vir Menslikehulpbronbestuur, 18(0), a1247. https://doi.org/ 10.4102/sajhrm.v18i0.1247

[11] Colquitt, J. A., Lepine, J. A., \& Wesson, M. J. (2019). Organizational behavior: Improving performance and commitment in the workplace. (6 ${ }^{\text {th }}$ ed.). New York: McGraw Hill Education Limited.

[12] Effendi, M., Matore, E. M., Rahman, N. A., Idris, H., Khairani, A. Z., \& Al Hapiz, N. M. (2020). Is adversity quotient (AQ) able to predict the academic performance of polytechnic students? Journal of Critical Reviews, 7(3), 393-398. http://dx.doi.org/10.31838/jcr.07.03.75.

[13] Fahmi, H. K., Musnadi, S., \& Nadirsyah. (2019). Role conflict, self-efficacy, employees' performance, and organizational performance. Journal of Accounting Research, Organization, and Economics, 2(1), 31-40.

[14] Falola, O., Osibanjo, A. O., \& Ojo, S. I. (2014). Effectiveness of training and development on employees' performance and organization competitiveness in the Nigerian Banking Industry. Bulletin of the Transilvania University of Braşov Series V: Economic Sciences, 7(56), 161-170.

[15] Hair, J. F., Babin, B. J., Anderson, R. E., \& Black, W. C. (2018). Multivariate data analysis (8 ${ }^{\text {th }}$ ed.). India: Cengage India.

[16] Hastuti, T. D., Sari, D. R., \& Riyadi. (2018). Student profile with high adversity quotient in math learning. IOP Conf. Series: Journal of Physics: Conf. Series, 983, 1-6.

[17] Hidayati, I. A., \& Taufik, T. (2020). Adversity quotient of outstanding students with limited conditions. Indigenous: Jurnal Ilmiah Psikologi, 5(2). 195-206. https://doi.org/10.23917/indigenous.v5i2.10823.

[18] Imran, M., \& Shahnawaz, M. G. (2020). PsyCap and performance: wellbeing at work as a mediator. Asia-Pacific Journal of Management Research and Innovation, 1-10. https://doi.org/10.1177/2319510X20915999.

[19] Ivancevich, J. M., Konopaske, R., \& Matteson, M. T. (2018). Organizational behavior and management (11th ed.). New York: McGraw Hill Company.

[20] Luthans, F., \& Youssef-Morgan, C. M. (2017). Psychological capital: An evidence-based positive approach. Reviews in Advance, 4, $339-366$. https://doi.org/10.1146/annurev-orgpsych-032516-113324

[21] Luthans, K. W., Luthans, B. C., \& Chaffin, T. D. (2018). Refining grit in academic performance: The mediational role of psychological capital. Journal of Management Education, 1-27. https://doi.org/10.1177/1052562918804282.

[22] Muztaba, Bahri, S., \& Farizal. (2020). The effects of adversity quotient and spiritual quotient on teacher performance. Asian Journal of Science Education, 2(1), 64-70. https://doi.org/10.24815/ajse.v2i1.15983.

[23] Ortega-Maldonado, A., \& Salanova, M. (2017). Psychological capital and performance among undergraduate students: The role of meaningfocused coping and satisfaction. Teaching in Higher Education, 1-14. https://doi.org/10.1080/13562517.2017.1391199.

[24] Puspitacandri, A., Warsono, Soesatyo, Y., Roesminingsih, E., \& Susanto, H. (2020). The effects of intelligence, emotional, spiritual, and adversity quotient on the graduates quality in Surabaya shipping polytechnic. European Journal of Educational Research, 9(3), $1075-1087$. https://doi.org/10.12973/eu-jer.9.3.1075

[25] Rodríguez-Cifuentes, F., Segura-Camacho, A., García-Ael, C., \& Topa, G. (2020). The mediating role of psychological capital between motivational orientations and their organizational consequences. International Journal of Environmental Research and Public Health, 17(13), 1-20. https://doi.org/10.3390/ijerph17134864.

[26] Runtu, D. Y. N., Aldrin, N., \& Merdiaty, N. (2019). Effect of work ethics on job performance with adversity quotient as a mediator. International Journal of Research in Business and Social Science, 8(5), 98-103. https://doi.org/10.20525/ijrbs.v8i5.457.

[27] Saif ur Rehman, Qingren, Latif, Y., \& Iqbal, P. (2017). Impact of psychological capital on occupational burnout and performance of faculty members. International Journal of Educational Management, 31(4), 455-469. https://doi.org/10.1108/IJEM-01-2016-0011.

[28] Saithong-in, S., \& Ussahawanitchakit, P. (2016). Psychological capital and job performance: An empirical research of certified public accountants (CPAs) in Thailand. The Business \& Management Review, 7(5), 499-506. http://dx.doi.org/10.2307/256287.

[29] Santos, A. S., Reis Neto, M. T., \& Verwaal, E. (2018). Does cultural capital matter for individual job performance? A large-scale survey of the impact of cultural, social, and psychological capital on individual performance in Brazil. International Journal of Productivity and Performance Management, 67(8), 1352-1370. https://doi.org/10.1108/IJPPM-05-2017-0110.

[30] Şen, C., \& Basim, H. N. (2018). The impact of psychological capital on job performance and cynicism: The moderator effect of cultural tightness-looseness. Social Sciences Studies Journal, 4(19), 2402-2423. https://doi.org/10.26449/sssj.648.

[31] Septria, S., \& Rusli, D. (2019). Pengaruh adversity quotient terhadap optimisme pada ibu yang mempunyai anak berkebutuhan khusus. Jurnal riset Psikologi, 4, 1-11. http://dx.doi.org/10.24036/jrp.v2019i4.7604.

[32] Siphai, S. Influences of moral, emotional, and adversity quotient on good citizenship of Rajabhat Universitys' students in the Northeast of Thailand. Academic Journal, 10(17), 2413-2421.

[33] Slåtten, T., Mutonyi, B. R., \& Lien, G. (2020). The impact of individual creativity, psychological capital, and leadership autonomy support on hospital employees' innovative behavior. BMC Health Services Research, 20(1096), 1-17. https://doi.org/10.1186/s12913-020-05954-4

[34] Stoltz, P. G. (2007). Adversity quotient: Turning obstacles into opportunities. Jakarta: PT Grasindo.

[35] Sujana, I. K., Suardikha, I. M. S., \& Pratiwi, N. P. T. W. (2019). The effect of intellectual intelligence, emotional intelligence, spiritual intelligence, and adversity intelligence on professional performance in the taxation field with locus of control as moderating variable. International Journal of Sciences: Basic and Applied Research (IJSBAR), 45(2), 53-63.

[36] Tahsildari, A., \& Shahnaei, S. (2015). Enhancing organizational effectiveness by performance appraisal, training, employee participation, and job definition. European Journal of Business and Management, 7(12), 56-67.

[37] Tang, Y., Shao, Y-F., \& Chen, Y-J. (2019). Assessing the mediation mechanism of job satisfaction and organizational commitment on innovative behavior: The perspective of psychological capital. Frontiers in Psychology, 10, 1-12. https://doi: 10.3389/fpsyg.2019.02699. 
[38] Tansiongco, L. A., \& Ibarra, F. P. (2020). Educational leaders' adversity quotient, management style and job performance: Implications to school leadership. Indonesian Research Journal in Education (IRJE), 4(2), 386-401.

[39] Tigchelaar, L., \& Bekhet, K. E. (2015). The relationship of adversity quotient and personal demographic profile of private business leaders in Egypt. International Journal of Sciences: Basic and Applied Research, 1, 403-422.

[40] Tüzün, I. K., Çetin, F., \& Basim, H. N. (2018). Improving job performance through identification and psychological capital. International Journal of Productivity and Performance Management, 67(1), 155-170, https://doi.org/10.1108/IJPPM-03-2016-0060.

[41] Uzoho, l., \& Akudo, F. U. (2021). Teachers' perception of principals' adversity quotient as a correlate of their job performance in public secondary schools in Anambra State, Nigeria. International Journal of Research (IJR), 8(8), 1-11.

[42] Van Griethuijsen, R. A. L. F., van Eijck, M. W., Haste, H., den Brok, P. J., Skinner, N. C., Mansour, N., Gencer, A. S., \& BouJaoude, A. (2014). Global patterns in students' views of science and interest in science. Research in Science Education, 45(4), 581603. https://doi.org/10.1007/s11165-014-9438-6.

[43] Wahyuningsih, D., \& Wulansari, N. A. (2016). The impact of psychological capital on nurse's performance: The mediating role of psychological well-being and work-family conflict. Management Analysis Journal, 5(4), 325-338. https://doi.org/10.15294/MAJ.V5I4.12663.

[44] Wang, Y., Chen, Y., \& Zhu, Y. (2021). Promoting innovative behavior in employees: The mechanism of leader psychological capital. Front. Psychol., 11:598090. https://doi: 10.3389/fpsyg.2020.598090

[45] Waters, L., Strauss, G., Somech, A., Haslam, N., \& Dussert, D. (2020). Does team psychological capital predict team outcomes at work? International Journal of Wellbeing, 10(1), 1-25. https://doi:10.5502/ijw.v10i1.923

[46] Widodo, W. (2019). Popular \& practical research methodologies (in Indonesia). Depok: Rajawali Pers.

[47] Wolor, C. W., Pratama, A., Aditya, S., Fadillah, N., \& Purwana, D. (2020). Adversity quotient in improving millennial generation salespeople's performance in the industrial revolution. Humanities \& Social Sciences Reviews, 8(1), 220-226. https://doi.org/10.18510/hssr.2020.8131.

[48] Yukongdi, V., \& Shrestha, P. (2020). The influence of affective commitment, job satisfaction and job stress on turnover intention: A study of Nepalese Bank Employees. Review of Integrative Business and Economics Research, 9, 88-98. 